Article

\title{
Nutritional Characterization of Two Rare Landraces of Turnip (Brassica rapa. var. rapa) Tops and Their On-Farm Conservation in Foggia Province
}

\author{
Giulia Conversa *(1), Corrado Lazzizera, Anna Bonasia, Paolo La Rotonda and Antonio Elia \\ Department of the Science of Agriculture, Food and Environment (SAFE), University of Foggia, \\ 71100 Foggia, Italy; corrado.lazzizera@unifg.it (C.L.); anna.bonasia@unifg.it (A.B.); \\ paolo.larotonda@unifg.it (P.L.R.); antonio.elia@unifg.it (A.E.) \\ * Correspondence: giulia.conversa@unifg.it
}

Received: 16 April 2020; Accepted: 6 May 2020; Published: 8 May 2020

check for updates

\begin{abstract}
The study of nutritional properties in landrace products and the general context of its cultivation site are crucial to designing a sustainable on-farm strategy for landrace conservation. The present study describes the main nutritional aspects of two Brassica rapa subspecies rapa landraces collected in Puglia, Italy along with agroecological and socioeconomical traits where they are cultivated. The two B. rapa landraces ('Cima di rapa dalla testa' and 'Cima di rapa antica') are only found in sites at 700-800 $\mathrm{m}$ asl and in two landscape units (the Southern Daunian Mountains (SDM) and the Umbra Forest (UF), respectively) of the Foggia province. These rare landraces were selected by farmers to produce turnip greens/tops from ancient root turnip crops. They are named and consumed by local people in the same way as turnip tops of Brassica rapa subspecies sylvestris ('Cima di rapa'), which are widely cultivated in Puglia. Compared to the most common 'Cima di rapa', the two highlighted landraces have a better nutritional profile linked to an improved content in antioxidant compounds-i.e., vitamin C (458 $\left.\mathrm{mg} \mathrm{kg}^{-1} \mathrm{FW}\right)$, total phenols (347 $\mathrm{mg}$ ac. gallic equivalent $\left.\mathrm{kg}^{-1} \mathrm{FW}\right)$-in glucosinolate $\left(741 \mu \mathrm{mol} \mathrm{kg} \mathrm{FW}{ }^{-1}\right.$, in 'Cima di rapa antica') and in minerals, such as $\mathrm{K}$. Both landraces are deemed as having a high risk of erosion. Few exemplars are cultivated in marginal lands and urban/peri-urban areas (SDM), or in isolated sites within the UF, which is a special protection zone within Gargano National Park. However, natural, cultural, and recreational tourism are the main economic activities in both landscape units.
\end{abstract}

Keywords: Cima di rapa; turnip greens; phenols; glucosinolates; vitamin C; landscape type; marginal land; traditional agriculture; cultural diversity

\section{Introduction}

Plant genetic resources are defined as 'any genetic material of plant origin that has actual or potential value for food and agriculture' and they are an important component of agriculture and food biodiversity [1]. The continuing erosion of crop genetic diversity hampers agroecosystem functions as well as provisioning (food and freshwater production), regulating (pest and disease control, pollination, carbon sequestration), and cultural (traditional knowledge, spiritual/religious and aesthetic values) ecosystem services [2,3].

One of the most threatened components of agricultural plant genetic resources is crop landrace (local variety) [4-6], which is defined as a crop that has never been subjected to formal plant breeding [7] and has developed its unique characteristics through in situ selection operated by growers, representing a constituent part of rural cultures and landscapes [8]. 
Preservation of landraces is timely and urgent because the rate of local genetic and cultural erosion is very high, hampering the potential for innovation in sustainable agriculture and for counteracting the decline in rural communities and cultural diversity $[9,10]$.

The Puglia region in the South of Italy is rich in local varieties of vegetables despite suffering from continuous genetic erosion [11]. Recently, in this region, a survey on vegetable crop landraces has been carried out, which proves that the province of Foggia is the most important for the abundance of these genetic resources [12]. In some areas of this province, two landraces of Brassica rapa subspecies rapa are still cultivated as leafy/bolting shoot vegetables. B. rapa subspecies rapa is one of the oldest cultivated root (turnip) plants used for human consumption. In European countries, many varieties of turnip were an important starch before potatoes were accepted as human food, while nowadays this subspecies of B. rapa is a neglected crop and most of its diversity has been lost $[13,14]$. Its landraces, however, are still popular in Portugal and Spain, where they are cultivated for roots (turnip), but mainly for consumption as leaves (turnip greens) and/or bolting shoots (turnip tops) $[15,16]$. In Italy, information about this vegetable is scarce. Some landraces are cultivated in very small areas, such as in the Friuli region as roots ("Rapa da Brovada", which have obtained the protected designation of origin (PDO) European label) and the Toscana region as root and leafy/bolting shoot vegetables (turnip greens and turnip tops) ("rapa pisana", included in the National Registry for the Biodiversity of Agricultural and Food interest). In southern Italy and mainly in Puglia, the most widespread Brassica rapa belongs to the subspecies sylvestris to produce the leafy/inflorescence vegetable known as 'Cima di rapa' (in Puglia region) or 'Friarelli' (in Campania region), also known as broccoli raab, rapini, or Italian turnip tip [11]. To the best of our knowledge, no landraces of $B$. rapa subspecies rapa are cultivated in southern Italy, at least as a leafy or leafy/bolting shoot vegetable. The two landraces found in Foggia may be considered a rare case of farmer's maintenance for this subspecies. For this reason, its preservation appears to be urgent.

In recent years, on-farm conservation has been proposed as an agro-biodiversity preservation strategy that allows evolutionary processes to continue $[17,18]$. For on-farm sustainable management and maintenance of landraces, the identification and the highlighting of the chemical and nutritional properties of their products may represent an added value that could promote the preference of consumers and hence their cultivation by farmers. However, sustainable strategies for on-farm conservation of landraces also needs information concerning the agroecological features $[17,19]$ and the socioeconomical contexts of the territory where they are cultivated [20-22].

In this view, the present study describes the main nutritional aspects (vitamin C, total phenols glucosinolate, and mineral contents and antioxidant capacity) of the two Brassica rapa subspecies rapa landraces collected in Foggia along with the agroecological and sociocultural-economic traits of the areas where they are collected.

\section{Materials and Methods}

\subsection{Territory Description}

The province of Foggia, also known as 'Daunia' or 'Capitanata', lies geographically between $41^{\circ} 54^{\prime} 44^{\prime \prime} \mathrm{N}$ and $41^{\circ} 02^{\prime} 27^{\prime \prime} \mathrm{N}$ in latitude and $14^{\circ} 55^{\prime} 58^{\prime \prime} \mathrm{E}$ and $14^{\circ} 02^{\prime} 27^{\prime \prime} \mathrm{E}$ in longitude.

The territory is divided by the regional territorial landscape plan (RTLP) into three different landscape types (LT), namely Gargano, Daunian Mountains, and Tavoliere (Figure 1) based on several factors including hydro-geo-morphological assessment, as well as the climatic, agroecological, and socioeconomic characteristics. Within each LT, the territorial landscape unit (LU) represents the smallest uniform territorial unit. A more extensive description of traits of the abovementioned landscape types and units of Foggia are reported in Conversa et al. [23], who evaluated the diversity status of the vegetable landraces of Foggia province by adopting a landscape-scale approach. The Gargano LT is characterized by the presence of the Gargano Promontory with a maximum elevation that exceeds $1000 \mathrm{~m}$ and covers 196,000 hectares. The urban area represents $14 \%$ of the total LT, with 200,000 inhabitants distributed over 17 villages. More than $50 \%$ of the total surface still maintains a medium to high 
ecological value due to the preservation of seminatural/natural ecosystems. Protected areas $(62 \%$ of the total) are represented by Gargano National Park. Agricultural activities are typical of marginal lands (almost $30 \%$ of the total) where grazing is widespread and the arable agriculture consists of non-irrigated crops along with olive groves, frequently placed on artificial terraces. Consistently, soils show a restriction level to cultivation ranging from limited to very severe or even unsuited to cultivation.

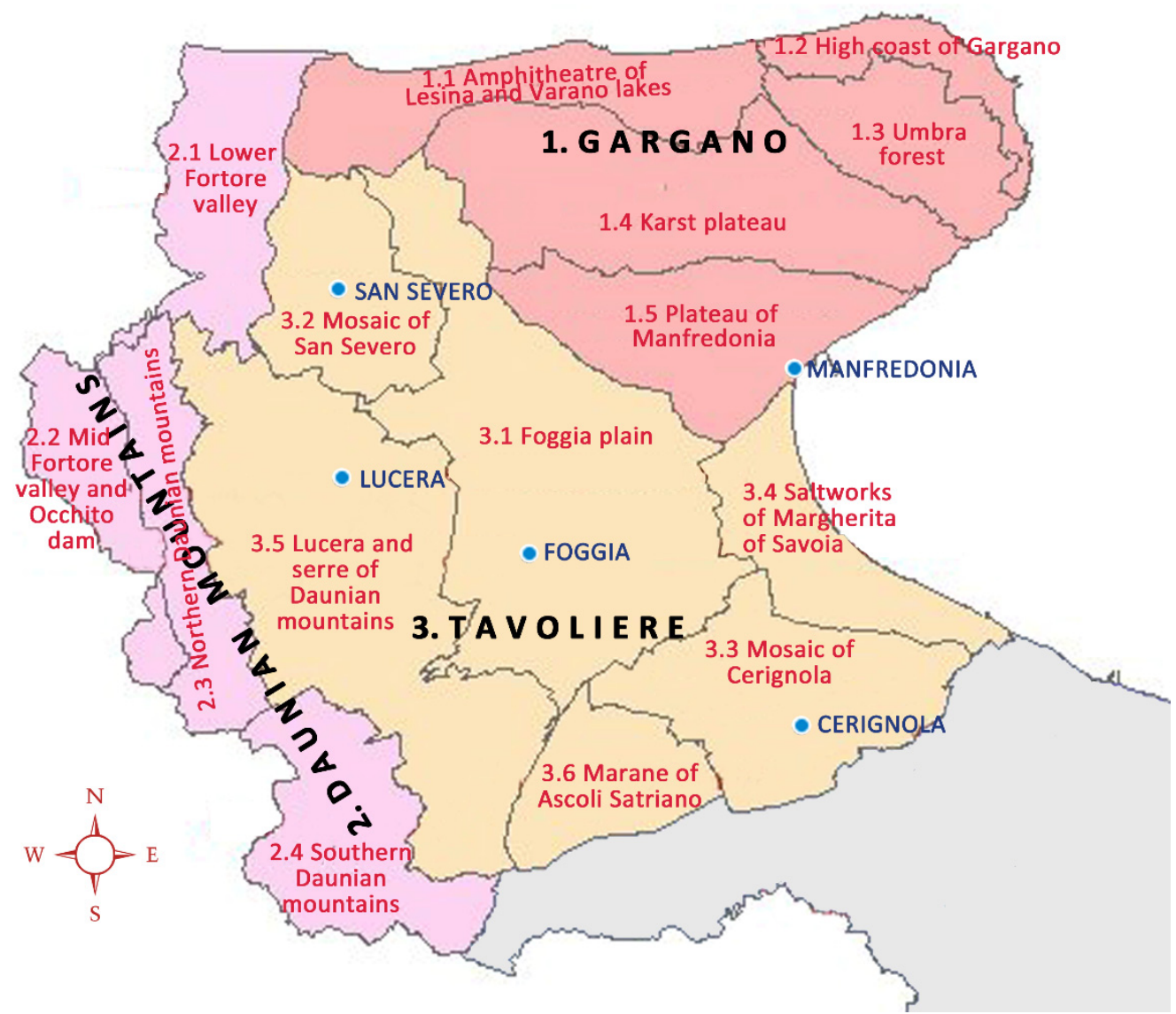

Figure 1. Landscape types (LT) (pink: Gargano; violet: Daunian Mountains; and yellow: Tavoliere), relative landscape units (LU) and the five most important cities in Foggia.

The Daunian Mountain LT is the smallest in the Foggia province, having a similar urban area but half of the population of Gargano, distributed over almost 30 small hill villages. Most natural areas (with some defined as protected areas) such as woodland, pasture, and uncultivated land covering 37,000 hectares occur in the northern and southern part of the Daunian Mountains. In these areas, the dominant agricultural land use includes non-irrigated arable crops (cereal and forage) (extensive crops) and permanent crops, mostly olive groves (5900 ha). Soils have restrictions to cultivation due to the risks of erosion and rooting-zone limitations.

The Tavoliere landscape type covers an area of about 352,400 hectares with an urbanized area representing $0.05 \%$ of the total territory. However, the Tavoliere is the most populated area in the province with its five biggest towns, whereas the countryside is almost uninhabited. About $90 \%$ of the area is a flat plain devoted to agriculture, mostly to extensive non-irrigated crops (i.e., durum wheat), followed by irrigated vegetables and tree crops, whereas natural lands and protected natural areas are very limited.

The lowest monthly mean temperatures are recorded in the Daunian Mountains $\left(3.6^{\circ} \mathrm{C}\right.$, in February), the highest in the Tavoliere $\left(25^{\circ} \mathrm{C}\right.$, in August) LT. Temperatures below $0{ }^{\circ} \mathrm{C}$ occur 
15-16 days annually in the Daunian Mountains. The annual mean rainfall is higher in the Daunian Mountains and Gargano (800 and $1100 \mathrm{~mm}$, respectively) than in the Tavoliere (400-500 mm).

\subsection{Sampling and Samples Preparation}

The studied landraces of Brassica rapa subspecies rapa were collected in the landscape unit 'Southern Daunian Mountains' (SDM) and 'Umbra Forest' (UF) within, respectively, the Daunian Mountains and Gargano LTs (Figure 1) from local growers who reported their maintenance for at least 50 years. The two studied landraces are cultivated in quite isolated areas of Foggia province, a long way from each to another $(100 \mathrm{~km})$ and separated by the wide and intensively cultivated plain area of the Tavoliere LT (Figure 1), so differing characteristics between them may be supposed as a consequence of independent selection performed year to year by local farmers.

In the SDM, the landrace was collected from two farmers in the town of Monteleone di Puglia ( $800 \mathrm{~m}$ above sea level-asl) and in the 'Umbra Forest' from two places within a large (100 ha) wildlife breeding farm at $700 \mathrm{~m}$ asl in the territory of Vico del Gargano. They developed a white-fleshed and tapered root (turnips) (Figure S1A), although local people usually consume the leaves (turnip greens) (Figure S1B) and/or flower buds and their surrounding leaves (turnip tops) (Figure S1C) in the same way as the Brassica rapa subspecies sylvestris (L.) Janch. product ('Cima di rapa'). The latter is widely cultivated and consumed in Puglia with many local varieties selected by farmers and differing in their flowering time [24].

The local name of the two studied landraces is 'Cima di rapa antica' (ancient Cima di rapa) collected in the UF, and 'Cima di rapa dalla testa' (head Cima di rapa) collected in the SDM LU. The name 'Cima di rapa' is used by local people because the parts consumed are very similar to those of the Brassica rapa subspecies sylvestris widely eaten throughout the region.

We considered as a control the only available comparable material, a B. rapa subspecies sylvestris genotype, despite it being botanically different from the Brassica rapa subspecies rapa. The $B$. rapa subspecies sylvestris genotype was bought at a Foggia market and here is referred to as the commercial genotype (CG).

Samples (4-5 kg) (shoots: leaves + stems + inflorescences) of both landraces were collected on 14 April 2017 and cold stored before being processed the day after, when the commercial genotype was bought.

In total, 40 to 50 flower sprouts (having a corymb $\sim 3 \mathrm{~cm}$ wide with completely closed flowers and 5-6 leaflets) (turnip tops) were separated from the sampled materials. They were pooled and then three replicates of 12-16 turnip tops were randomly selected. After well mixing the tops of each replication, three subsamples (approximately $150 \mathrm{~g}$ ) were formed.

The dry matter (DM) content, ascorbic acid, dehydroascorbic acid, vitamin C, glucosinolate, total phenols, inorganic anion, cation concentrations, and total antioxidant capacity of turnip tops were measured. All subsamples were analyzed in triplicate. In order to determine the DM, fresh plant material was dried in a thermo-ventilated oven at $70^{\circ} \mathrm{C}$ until reaching a constant mass.

\subsection{Chemical Analysis}

The total content of vitamin C - ascorbic acid (AsA) + de-hydro-ascorbic acid (DHAA) -was measured in lyophilized samples (0.3 g) using a chromatographic system (ICS 3000 System, Dionex, Sunnyvale, CA, USA) equipped with a UV-visible detector (RLSC Diode Array Detector, Dionex, Sunnyvale, CA, USA) and a $5 \mu \mathrm{m}$ reverse-phase column (C18) (Acclaim 120, Dionex, Sunnyvale, CA, USA) (temperature set at $30^{\circ} \mathrm{C}$ ).

Ascorbic acid was extracted according to the modified method of Koh et al. [25]. DHAA was reduced with dithiothreitol in order to determine the total content of vitamin C (AsA + DHAA) and, indirectly, the DHAA content. Reduced samples were also injected into the chromatographic system. AsA was identified and quantified by retention time and spectra. The flow rate was fixed at $1 \mathrm{~mL} \mathrm{~min}{ }^{-1}$. 
The detection wavelength was $254 \mathrm{~nm}$ and the UV spectra were in the 190-350 nm range. The method was calibrated with a curve of standard AsA solution. Results were expressed on a fresh weight basis.

Total polyphenols were determined as reported in Bonasia et al. [26]. Briefly, lyophilized spears were double extracted in water/methanol (20:80, v/v) solution and centrifuged. Total phenol (TP) content was determined by mixing the methanolic extracts with the Folin-Ciocalteu reagent. The absorbance was read at $750 \mathrm{~nm}$. The results are expressed as gallic acid equivalents (GAE) $\mathrm{mg} \mathrm{kg}^{-1}$ of fresh weight using a calibration curve.

Glucosinolate (GLS) extraction and desulphation from lyophilized turnip tips was carried out as reported in Conversa et al. [27]. The de-sulphoglucosinolates (d-GLSs) were separated using a gradient High Performance Liquid Chromatography method with an Ion Chromatography System 3000 System (Dionex, Sunnyvale, CA, USA) using a $10 \mu \mathrm{L}$ injection loop, C18 $(5 \mu \mathrm{m})$ reverse-phase ion-exchange columns (Kinetex Core-Shell, Phenomenex, Torrance, CA, USA) combined with a UV-visible detector (RLSC Diode Array Detector, Dionex, Sunnyvale, CA, USA) set to a wavelength of $229 \mathrm{~nm}$. The oven temperature was set at $35^{\circ} \mathrm{C}$. Compounds were separated using the following program, with a flow rate of $0.8 \mathrm{~mL} \mathrm{~min}^{-1}: 1 \mathrm{~min}$ at $100 \% \mathrm{H}_{2} \mathrm{O} ; 49 \mathrm{~min}$ gradient from $0 \%$ to $25 \%(v / v)$ ethanol; $4 \mathrm{~min}$ gradient to return to $100 \% \mathrm{H}_{2} \mathrm{O} ; 10 \mathrm{~min}$ at $50 \%$ acetonitrile/water $(v / v)$; final $10 \mathrm{~min}$ at $100 \% \mathrm{H}_{2} \mathrm{O}$. Individual GLSs were identified by comparing retention times with those of available GLS standards and certified glucosinolate levels of certified reference materials recommended by the EU and ISO (BC 367). The results are expressed on a fresh weight basis.

The antioxidant capacity (AC) was determined by ABTS assay based on the formation of the radical ABTS $^{+}$by the reaction of ABTS [2,2-Azino-bis(3-ethyl-benzothiazoline-6-sulphonic acid)] (7 $\mathrm{mM} \mathrm{L}^{-1}$ ) with $140 \mathrm{mM} \mathrm{L}^{-1}$ of potassium persulphate as reported by Conversa et al. [28]. In brief, $20 \mu \mathrm{L}$ of the extract was reacted with $1 \mathrm{~mL}$ of $\mathrm{ABTS}^{+}$radical. The hydrophilic fraction was extracted twice from lyophilized samples using $80 \%(\mathrm{v} / \mathrm{v})$ methanol in a shaking water bath $\left(22^{\circ} \mathrm{C}\right)$ for $15 \mathrm{~min}$ and by centrifugation $(13,000 \mathrm{rpm} ; 10 \mathrm{~min})$. The supernatants were combined. The lipophilic components were extracted twice with $1 \mathrm{~mL}$ of hexane, using the above conditions. The antioxidant activity was assessed as TEAC (trolox equivalent antioxidant capacity) according to Pellegrini et al. [29] and expressed on a fresh weight basis.

Inorganic cation and anion were analyzed by ion chromatography (Dionex ICS 3000; Dionex Corp., Sunnyvale, CA, USA) equipped with an isocratic pump, conductivity detector, and an auto-sampler (Dionex ${ }^{\mathrm{TM}}$ AS-DV, ThermoFisher Scientific, Waltham, MA, USA). Inorganic cations were extracted from lyophilised samples $\left(1 \mathrm{~g}\right.$ ), previously ashed (in a muffle furnace at $550^{\circ} \mathrm{C}$ for $6 \mathrm{~h}$ ), and acid digested ( $20 \mathrm{~mL}$ of $1 \mathrm{~mol} \mathrm{~L}^{-1} \mathrm{HCl}$ in boiling water for $30 \mathrm{~min}$ ), before injection into the ion chromatography system. A self-generating DRS-600 suppressor $(4 \mathrm{~mm})$ (ThermoFisher Scientific, Waltham, MA, USA) was used with an analytical column $(4 \mathrm{~mm} \times 250 \mathrm{~mm})$ Dionex IonPack CS12A (Dionex Corp., Sunnyvale, CA, USA), and an eluent solution ( $20 \mathrm{mM}$ methanesulfonic acid) at a flow rate of $1 \mathrm{~mL} \mathrm{~min}^{-1}$.

Inorganic anions were extracted from the lyophilized sample $(0.5 \mathrm{~g})$ with $50 \mathrm{~mL}$ of eluent solution ( $3.5 \mathrm{mM}$ sodium-carbonate and $1.0 \mathrm{mM}$ sodium-bicarbonate) in a shaking water bath at room temperature for $30 \mathrm{~min}$. The mixture was filtered through Whatman $\mathrm{n} .2$ paper. The filtrates were filtered again through a $0.22 \mu \mathrm{M}$ Millipore filter, before injection into the ion chromatography system using a self-generating ERS-500 suppressor ( $4 \mathrm{~mm}$ ) (ThermoFisher Scientific, Waltham, MA, USA), an analytical column $(4 \mathrm{~mm} \times 250 \mathrm{~mm}$ ) Dionex Ion-Pac AS23 (Dionex Corp., Sunnyvale, CA, USA), and an eluent solution ( $3.5 \mathrm{mM}$ sodium-carbonate and $1.0 \mathrm{mM}$ sodium-bicarbonate) at a flow rate of $1 \mathrm{~mL} \mathrm{~min}^{-1}$.

\subsection{Statistical Analysis}

A one-way analysis of variance was performed using Statistical Analysis Software (SAS, Cary, NC, USA). The least significant difference (LSD) test $(p=0.05)$ was used to establish differences between means. 


\section{Results and Discussion}

\subsection{Nutritional Characterization of Landraces}

\subsubsection{Dry Matter, Vitamin C, and Total Phenols}

The dry matter (DM) content was higher in two landraces of rapa subspecies compared to the commercial genotype (CG) of the sylvestris subspecies, having thicker leaflets probably because of an adaption response to the lower temperatures occurring in the hilly/mountain climate, particularly in the 'Cima di rapa dalla testa' of the Southern Dauninan Mountains (Table 1).

Table 1. Dry mass (DM) and main antioxidant compound concentrations in turnip tops of two landraces of B. rapa subspecies rapa from Foggia.

\begin{tabular}{|c|c|c|c|c|c|}
\hline Genotype & $\begin{array}{c}\text { Dry Mass } \\
\text { Concentration } \\
\left(\mathrm{g} \mathrm{kg}^{-1} \mathrm{FW}\right)\end{array}$ & Ascorbic Acid & $\begin{array}{c}\text { De-Hydro-Ascorbic } \\
\text { Acid } \\
\text { (mg kg }{ }^{-1} \text { FW) }\end{array}$ & Vitamin C & $\begin{array}{c}\text { Total Phenol } \\
\text { (mg GAE } \ddagger \text { kg }^{-1} \text { FW) }\end{array}$ \\
\hline Cima di rapa antica & $153.0 \pm 1.7 \mathrm{~b}^{1}$ & $251.0 \pm 6.5 \mathrm{a}$ & $169.7 \pm 15.1 b$ & $420.7 \pm 19.9 b$ & $304.6 \pm 18.3 \mathrm{a}$ \\
\hline Cima di rapa dalla testa & $174.4 \pm 2.3 \mathrm{a}$ & $240.7 \pm 11.9 \mathrm{a}$ & $254.5 \pm 31.9 \mathrm{a}$ & $495.2 \pm 20.9 a$ & $389.7 \pm 47.0 \mathrm{a}$ \\
\hline Commercial & $119.0 \pm 8.2 c$ & $196.2 \pm 11.9 b$ & $119.8 \pm 9.1 b$ & $316.0 \pm 19.0 \mathrm{c}$ & $216.4 \pm 16.3 b$ \\
\hline Significance $^{2}$ & $* * *$ & $* * *$ & $* * *$ & $* * *$ & $* * *$ \\
\hline
\end{tabular}

${ }^{\ddagger}$ GAE, gallic acid equivalent. ${ }^{1}$ Means $( \pm \mathrm{SE}$ of mean) in columns not sharing the same letters are significantly different according to Least Significance Difference test $(p=0.05) .{ }^{2} \mathrm{~ns}$, and ${ }^{* * * *}$, not significant or significant at $p \leq 0.001$, respectively.

Both also had higher vitamin C content (on a fresh weight basis) compared to the CG, probably due to their greater DM content (Table 1). This confirms previous research that, in general, Brassica vegetables that grown under low-temperature regimes show a higher vitamin $C$ content [30]. Ascorbic acid (AsA) is the main biologically active form of vitamin C. It is essential in defence against environmentally induced oxidative stress, interacting with the damaging free radicals with the oxidation to dehydroascorbic acid (DHAA) both in plant and animal cells [31]. In plants, DHAA is recycled to AsA or irreversibly hydrolyzed [32] and its amount is modulated by AsA and AsA-regenerating enzyme responsiveness to stress factors such as light, temperature, salinity and drought stress [31]. Since in the 'Cima di rapa dalla testa' landrace the dehydroascorbic acid was proved mostly to contribute to vitamin C content (Table 1), it can be speculated that this landrace experienced more stressing climatic and/or growing conditions which resulted in a poorer redox state of tissues. Among leafy vegetables belonging to Brassica rapa species, the level of vitamin C changes from 253-450 (var. chinensis), 200-290 (var. pekinensis), 130 (var. perviridis), and 460 (var. parachinensis) $\mathrm{mg} \mathrm{kg}^{-1} \mathrm{FW}$ [33]. Compared with the latter, the studied landraces generally showed a higher level (458 $\mathrm{mg} \mathrm{kg}^{-1} \mathrm{FW}$, on average) although less than values reported in previous studies for turnip greens $\left(620-818 \mathrm{mg} \mathrm{kg}^{-1} \mathrm{FW}\right)[34,35]$ and turnip tops (460-899 $\left.\mathrm{mg} \mathrm{kg}^{-1} \mathrm{FW}\right)[34,35]$ grown in northwestern Spain. It is noteworthy that the two landraces are richer in vitamin $\mathrm{C}$ compared with the subspecies sylvestris genotype evaluated both in this research $(+0.44 \%)$ (Table 1) and in other studies performed in Puglia $\left(255 \mathrm{mg} \mathrm{kg}^{-1} \mathrm{FW}^{-1}\right.$ [27]; $\left.266 \mathrm{mg} \mathrm{kg}^{-1} \mathrm{FW}^{-1}[36]\right)$.

Phenolic compounds are one of the most important groups among antioxidant phytochemicals [37]. They refer to a large number of compounds widely represented in the plant kingdom as they are involved in the plant response to both biotic (insect attack and pathogen infection) and abiotic stresses (light, temperature, nutrient supplies, water availability, growing conditions, and UV radiation) [38]. They have been reported to possess many beneficial properties for human health including the prevention of cancer, ageing, atherosclerosis, and neurodegenerative diseases [39].

In this work, the concentration of total phenols (TP) (on a fresh weight basis) was similar between the two landraces, which was $61 \%$ higher than the commercial genotype. In the subspecies sylvestris lower levels of TP (245 $\left.\mathrm{mg} \mathrm{kg}^{-1} \mathrm{FW}\right)$ have also been found by other authors [27]. 
In general, B. rapa crops are reported to contain a high amount of phenolic compounds, even higher than those of other Brassicaceae species, in particular in turnip greens and turnip tops $[38,40]$, and references therein. In previous studies performed on the Spanish B. rapa subspecies rapa genotypes, the concentration of TP in turnip tops (143 mg GAE $100 \mathrm{~g}^{-1} \mathrm{FW}$ ) [35] was very similar (Table 1) or slightly higher (15-39 $\left.\mathrm{mol} \mathrm{g}^{-1} \mathrm{DW}\right)[34,41]$ than our results $\left(12 \mu \mathrm{mol} \mathrm{g}^{-1} \mathrm{DW}\right.$, on average). Much greater contents of TP were instead detected by other authors [15,42] in buds $\left(10-19 \mathrm{~g} \mathrm{~kg}^{-1} \mathrm{DW}\right.$, which correspond to $\left.106-202 \mu \mathrm{mol} \mathrm{g}^{-1} \mathrm{DW}\right)$ and leaves and stems $\left(8-13 \mathrm{~g} \mathrm{~kg}^{-1} \mathrm{DW}\right)$ [15] of B. rapa subspecies rapa landraces cultivated in Portugal.

This contrasting evidence is not surprising since phenols are very susceptible to changes in environmental conditions being affected by the abovementioned abiotic and biotic stresses, as well as other secondary metabolites present in Brassica crops [38].

Both in the Spanish and Portuguese genotypes, among the 14-16 identified phenols, flavonoid kaempferol, quercetin and isorhamnetin have been reported as the most represented ones [15,41,42], also confirmed in B. rapa subspecies sylvestris characterization [43], playing a significant role as antioxidants [44-46] for the protection and preservation of human health.

\subsubsection{Glucosinolates}

Glucosinolates (GLSs) are a major group of plant secondary metabolites that are mainly present in the Brassicaceae family. They are $\beta$-thioglucosides- $\mathrm{N}$-hydroxysulfates derived from amino acid methionine (aliphatic GLS), tryptophan (indolyl GLS), and tyrosine or phenylalanine (aromatic GLSs) [47]. Glucosinolates are very important in human nutrition, as upon plant cellular disruption they are hydrolyzed by the myrosinase action to various bioactive breakdown products (isothiocyanates, nitriles, thiocyanates, epithionitriles, and oxazolidines). Hence, the anticarcinogenic properties of Brassica vegetables have mainly been ascribed to the GLS hydrolytic products such as isothiocyanates-e.g., sulphoraphane, indole-3-carbinol (I3C), and phenethyl isothiocyanate derived, respectively, from glucoraphanin, glucobrassicin, and gluconasturtiin $[48,49]$.

The detected GLSs were the same in the two landraces, namely three aliphatics (gluconapoleiferin, gluconapin, and glucobrassicanapin), the indolic glucobrassicin, and the aromatic gluconasturtiina (Table 2), whereas in the CG two unidentified GLSs were also detected, but at a low level $(7.78 \pm 1.4$ and $14.6 \pm 8.6 \mu \mathrm{mol} \mathrm{kg} \mathrm{FW}^{-1}$ ).

Table 2. Profile and concentration of glucosinolates in turnip tops of two landraces of B. rapa subspecies rapa from the province of Foggia.

\begin{tabular}{|c|c|c|c|c|c|c|}
\hline Genotype & GNL & GNA & $\begin{array}{l}\text { GBN } \\
\quad \mu \mathrm{mol} \mathrm{kg}\end{array}$ & $\begin{array}{r}\text { GBC } \\
W^{-1}\end{array}$ & GNS & Total \\
\hline Cima di rapa antica & $356.0 \pm 62.9 \mathrm{a}^{1}$ & $193.1 \pm 26.6 \mathrm{a}$ & $103.9 \pm 15.5 \mathrm{a}$ & $5.4 \pm 0.8 \mathrm{a}$ & $82.9 \pm 12.3 \mathrm{a}$ & $741.3 \pm 99.9 a$ \\
\hline Cima di rapa dalla testa & $77.2 \pm 2.9 \mathrm{~b}$ & $42.8 \pm 5.3 b$ & $165.8 \pm 44.0 \mathrm{a}$ & $0.2 \pm 0.09 c$ & $31.0 \pm 2.9 \mathrm{~b}$ & $317.0 \pm 47.8 b$ \\
\hline Commercial & $164.4 \pm 39.0 \mathrm{~b}$ & $84.4 \pm 1.6 b$ & $42.6 \pm 6.8 b$ & $2.3 \pm 0.4 b$ & $23.7 \pm 7.5 b$ & $317.4 \pm 59.0 \mathrm{~b}$ \\
\hline Significance $^{2}$ & $* *$ & $* * *$ & $* *$ & $* * *$ & $* * *$ & $* * *$ \\
\hline
\end{tabular}

${ }^{1}$ Means ( \pm SE of mean) in columns not sharing the same letters are significantly different according to Least Significance Difference test $(p=0.05) .^{2 * *}$ and ${ }^{* * *}$, significant at $p \leq 0.01$, and $p \leq 0.001$, respectively. GNL $=$ Gluconapoleiferin; GNA = Gluconapin; GBN = Glucobrassicanapin; GBC = Glucobrassicin; GNS = Gluconasturtiin.

Variability in GLSs concentration is reported in Brassica to be greatly affected by the environmental conditions (climate, growth factors such as soil texture, sulfate, and nitrogen fertilization) in interaction with genetic factors, whereas genetic factors are largely known to determine glucosinolates profile [50] and references therein.

In this study, regardless of variability between the genotypes, the total GLS levels (4.8-1.8 in terms of $\mu \mathrm{mol} \mathrm{g}{ }^{-1} \mathrm{DW}$ ) is much lower compared to those registered in Spanish turnip greens and turnip tops which ranged from 11.8-74 $\mu \mathrm{mol} \mathrm{g}^{-1}$ DW [47], 18.4-41.7 $\mu \mathrm{mol} \mathrm{g}^{-1}$ DW [41]. Higher GLS levels in Spanish turnip greens and turnip tops were also confirmed by other Authors reporting mean values of $12.9 \mu \mathrm{mol} \mathrm{g}^{-1}$ DW [34] or $29 \mu \mathrm{mol} \mathrm{g}^{-1}$ DW [16]. High GLS contents $\left(50 \mu \mathrm{mol} \mathrm{g}^{-1} \mathrm{DW}\right)$ have also 
been reported on average for flower buds of east-Asian countries (China, Japan, and Korea) B. rapa genotypes [51].

In general, the composition in GLSs of both landraces and CG is in agreement with that observed in 82 varieties of many subspecies of Brassica rapa [52]. In the latter, the aliphatic GLSs (mainly gluconapin) were predominant compared to the indolic ones (mainly glucobrassicin) and only one aromatic GLS (gluconasturtiin) was found out of 14 different GLSs identified.

Padilla et al. [47], Francisco et al. [41], and Cartea et al. [16] found 12-18 GLSs with aliphatic (mainly gluconapin and glucobrassicanapin) as the most abundant class and very low levels of indolic and aromatic (gluconasturtiin) ones on 113,10, and 45 varieties of $B$. rapa subspecies rapa from two locations in Spain. Despite finding a more limited composition of GLSs (only five), the prevalence of the aliphatic class is confirmed as is the presence of the aromatic glucosinolate gluconasturtiin. However, in our genotypes, the most abundant GLS is gluconapoleinferin (Table 2) rather than gluconapin and glucobrassicanapin, as reported by other authors [16,41,47,53]. Padilla [47] only recorded high levels of gluconapoleinferin for four of the studied varieties with an atypical glucosinolate pattern and they suggested that these characteristics were genetically fixed.

Such differences, as well as the environmental conditions, could be attributed to genetic traits of the two studied landraces along with the CG. The selection performed by the local farmers was probably addressed to lowering the bitterness and pungency of turnip greens and tops, which is related to GLS composition. Great amounts of gluconapin and progoitrin have been highly correlated with a bitter taste and after taste persistence respectively in Spanish turnip greens and turnip tops [54]. High gluconapin content has also been positively correlated to bitter taste in flower buds of east-Asian B. rapa genotypes [51]. These GLSs along with sinigrin and glucobrassicanapin are considered responsible for the low consumer acceptability of some Brassica crops $[55,56]$.

\subsubsection{Antioxidant Capacity}

The total antioxidant capacity (TAC) measures the efficiency of all antioxidant compounds in scavenging free radicals and is due to the contribution of both hydrophilic and lipophilic components and their interactions.

In this study, genotypes exhibited a clear difference in TAC with much higher values in 'Cima di rapa dalla testa' compared with 'Cima di rapa antica' and CG (by 1.7 and 2.4 fold, respectively) due to both lipophilic and especially hydrophilic components (Table 3). The hydrophilic component is strongly linked to the TP and vitamin C contents. Glucosinolates mostly act as indirect antioxidants through their break-down products [57], even if they may act as direct antioxidants [58], however their TAC measured through an ABTS assay (also used in this work) has been reported to be very low [49]. Based on that, it is possible to relate the higher TAC in both 'Cima di rapa dalla testa' and 'Cima di rapa antica' compared with CG to their greater content of vitamin $C$ and total phenols while the highest vitamin C content in 'Cima di rapa dalla testa' made the difference in hydrophilic AC compared with 'Cima di rapa antica' (Table 1). The contribution of the lipophilic antioxidant capacity, represented by antioxidant compounds such as carotenoids and vitamin E, seems to be not negligible $(10 \%-14 \%$ of TAC) and deserves further study. However, it shows a trend similar to hydrophilic AC underlining as a whole a greater antioxidant content for 'Cima di rapa dalla testa'.

\subsubsection{Mineral Content}

Anion and cation concentration is reported in Tables 4 and 5, respectively. Among anions, in all samples the level of nitrate is very low ( $95 \mathrm{mg} \mathrm{kg}^{-1} \mathrm{FW}$, on average), similar to that determined in tops of $B$. rapa subspecies sylvestris genotypes grown Puglia region [24,27]. Among plant products, nitrate is accumulated mainly in leafy vegetables and its assumption is linked to some human diseases [59] so a low content in this inorganic anion contributes to enhancing the quality traits of vegetables. Cima di rapa antica had the greatest content in phosphate and the lowest in chloride. The two landraces stand out for their K concentration, which was much higher than the CG, while they showed lower levels of 
$\mathrm{Ca}$ and $\mathrm{Mg}$. However, as a whole, these products showed greater contents of these nutritional minerals compared to the data reported by the Italian Council for Agricultural Research and Economics (CREA) for 'Cima di rapa' (3700 and $970 \mathrm{mg} \mathrm{kg}^{-1} \mathrm{FW}$ for $\mathrm{K}$ and Ca, respectively) and were comparable to various brassica leafy vegetables belonging to B. oleracea and B. rapa (subspecies pekinensis, chinensis, perviridis and rapa) selected along with onion, carrots, and potatoes from UK and US food composition tables for the highest content in $\mathrm{K}, \mathrm{Ca}$, and $\mathrm{Mg}$ [60].

Table 3. Antioxidant activity in turnip tops of two landraces of B. rapa subspecies rapa from province of Foggia.

\begin{tabular}{cccc}
\hline Genotype & Total & $\begin{array}{c}\text { Antioxidant Capacity } \\
\text { Hydrophilic } \\
\boldsymbol{\mu m o l ~ T E} \neq \mathbf{k g}^{-\mathbf{1}} \mathbf{~ F W}\end{array}$ & Lipophilic \\
\hline Cima di rapa antica & $1625 \pm 64 \mathrm{~b}^{1}$ & $1411 \pm 63 \mathrm{~b}$ & $213.8 \pm 11.8 \mathrm{~b}$ \\
Cima di rapa dalla testa & $4464 \pm 239 \mathrm{a}$ & $3808 \pm 207 \mathrm{a}$ & $656.1 \pm 50.8 \mathrm{a}$ \\
Commercial & $1080 \pm 70 \mathrm{c}$ & $975 \pm 65 \mathrm{c}$ & $104.8 \pm 9.4 \mathrm{c}$ \\
Significance $^{2}$ & $* * *$ & $* * *$ & $*$ \\
\hline
\end{tabular}

${ }^{\ddagger}$ Trolox Equivalent; ${ }^{1}$ Means ( \pm SE of mean) in columns not sharing the same letters are significantly different according to Least Significance Difference test $(p=0.05) .{ }^{2} \mathrm{~ns}$, and ${ }^{* * *}$, not significant or significant at $p \leq 0.001$, respectively.

Table 4. Concentration of inorganic anions in turnip tops of two landraces of B. rapa subspecies rapa from Foggia.

\begin{tabular}{|c|c|c|c|c|}
\hline \multirow{2}{*}{ Genotype } & $\mathrm{Cl}^{-}$ & $\mathrm{NO}_{3}{ }^{-}$ & $\mathrm{PO}_{4}{ }^{3-}$ & $\mathrm{SO}_{4}{ }^{2-}$ \\
\hline & \multicolumn{4}{|c|}{$\mathrm{mg} \mathrm{kg} \mathrm{FW}^{-1}$} \\
\hline Cima di rapa antica & $203.7 \pm 11.4 c^{1}$ & $114.3 \pm 14.7 b$ & $1688 \pm 78 a$ & $1613 \pm 69 a$ \\
\hline Cima di rapa dalla testa & $323.3 \pm 35.0 \mathrm{~b}$ & $87.0 \pm 18.8 \mathrm{~b}$ & $796.5 \pm 97 b$ & $1545 \pm 215 a$ \\
\hline Commercial & $413.1 \pm 11.6 \mathrm{a}$ & $82.6 \pm 20.3 b$ & $977.4 \pm 50 b$ & $1750 \pm 48 a$ \\
\hline Significance $^{2}$ & $* * *$ & $* *$ & $* * *$ & ns \\
\hline
\end{tabular}

1 Means ( \pm SE of mean) in columns not sharing the same letters are significantly different according to Least Significance Difference test $(p=0.05) .{ }^{2} \mathrm{~ns},{ }^{* *}$ and ${ }^{* * *}$, not significant or significant at $p \leq 0.01$, and $p \leq 0.001$, respectively.

Table 5. Concentration of inorganic cations in turnip tops of two landraces of B. rapa subspecies rapa from Foggia.

\begin{tabular}{ccccc}
\hline Genotype & $\mathbf{N a}^{+}$ & $\mathbf{K}^{+}$ & $\mathbf{M g}^{2+}$ & $\mathbf{C a}^{2+}$ \\
& & \multicolumn{2}{c}{$\mathbf{m g ~ k g}^{\mathbf{- 1}} \mathbf{F W}$} & \\
\hline Cima di rapa antica & $118.2 \pm 6.7 \mathrm{~b}^{1}$ & $5134 \pm 81 \mathrm{a}$ & $92.6 \pm 8.5 \mathrm{~b}$ & $1186 \pm 73 \mathrm{~b}$ \\
Cima di rapa dalla testa & $233.0 \pm 21.1 \mathrm{a}$ & $5179 \pm 372 \mathrm{a}$ & $112.8 \pm 11.9 \mathrm{~b}$ & $1580 \pm 69 \mathrm{~b}$ \\
Commercial $^{2}$ & $157.6 \pm 17.4 \mathrm{~b}$ & $3663 \pm 34 \mathrm{~b}$ & $221.3 \pm 5.7 \mathrm{a}$ & $2025 \pm 59 \mathrm{a}$ \\
Significance $^{2}$ & $* * *$ & $* * *$ & $* *$ & $*$ \\
\hline
\end{tabular}

1 Means ( \pm SE of mean) in columns not sharing the same letters are significantly different according to Least Significance Difference test $(p=0.05) .{ }^{2} \mathrm{~ns}$, and ${ }^{* * *}$, not significant or significant at $p \leq 0.001$, respectively.

\subsection{Landrace Conservation and Agroecological and Socio-Economic Territorial Traits}

The two B. rapa landraces found in the SDM and UF LUs can be considered as residuals of ancient turnip crops. In the past, the turnip is reported to have been cultivated in many areas of Southern Italy as a root crop to be used for food and animal feed [23] as it develops a fleshy root as a reservoir organ. The turnip probably ceased to be a vegetable, providing a reliable source of food after the introduction of the potato cultivation, as also reported for turnip cultivation in other areas of Europe [14]. In Foggia, potato cultivation was promoted in the early 1800s, yet it is likely that turnip cultivation may have been maintained by farmers in the mountainous lands such as the Daunian Mountains and Gargano LTs due to its cold and frost resistance [23]. Therefore, it started to be selected for producing fast-growing and vigorous leaves (turnip greens) and/or numerous and vigorous flowering shoots (turnip tops). 
This could explain the discovery of local varieties of B. rapa var rapa in the only two mountainous areas of Puglia while B. rapa subspecies sylvestris is widespread in areas on the plains [61].

Both landraces are cultivated on marginal land using low input traditional/ancient cultivation methods, without the use of chemicals as usually reported for landraces in Italy and Europe [1,20]. The turnip greens (Figure S1B) are harvested throughout the vegetative period (autumn) while for turnip tops it is after bolting (Figure S1C), which occurs in late winter as they require a prolonged cold exposure before flowering [62]. They are used as an ingredient in stews and soups and typical dishes. In particular, like varieties of the subspecies sylvestris, they are also used to prepare the 'orecchiette e cima di rapa' dish which is included in the 'List of Traditional Agro-food Products' of the Italian Department for Agriculture.

They are maintained in LUs differing in some agroecological and socioeconomic aspects. The Southern Daunian Mountains LU is characterized by two river valleys and several small villages, mostly with ageing populations on the top of the hills surrounding these valleys. These villages are connected to each other and to the main towns in the plain area of Tavoliere by a poor road network. The area is mainly devoted to forage and cereal cultivation; however, it is one of the richest provincial areas for vegetable landraces [23]. Along with several vegetable landraces, the 'Cima di rapa dalla testa' was found mainly in urban/peri-urban areas of many villages of the Southern Daunian Mountains LU, but it is also cultivated in Franco-Provençal municipalities of neighboring Northern Daunian Mountains landscape [63]. All of these vegetable landraces are cultivated in many cases by part-time growers, for family consumption but also sold to local markets. This suggests that these traditional cultivations still have importance as a food supply for the people living in the area, probably as a consequence of the increasing ageing of the population and the isolation from the greater urban centres in the plain area (Tavoliere LT).

The 'Cima di rapa antica' was found in the inner part Umbra Forest LU (Figure 1), which is a special protection zone within the Gargano National Park, scarcely populated and scarcely devoted to agriculture with mainly agro-silvopastoral systems as well as some artificial terraces of olive and almond groves. For this reason, this landrace is less frequent than 'Cima di rapa dalla testa' and it is only maintained by a few farmers for family consumption. However, both can be deemed at high risk of erosion considering the old age of the germplasm-owners and their cultivation mainly in few exemplars and for private use.

It is interesting to underline that in both LUs, tourism represents an economic benefit, though it is probably still not completely exploited. The Umbra Forest, belonging to the Gargano National Park, is important for nature tourism with many agritourism facilities and typical restaurants. Moreover, it is well connected with the neighboring coastal area (High Coast of Gargano LU) (Figure 1) where a huge increase in population occurs due to both nature and beach tourism, especially during the summer. Both the Southern and Northern Daunian Mountains are also important centers for natural and cultural/recreational tourism. In these contexts, traditional low-input and biodiversity-saving agriculture and its associated activities may play an eminent role in consolidating the combination of protection and enjoyment, which has relevance not only for protected areas but for the entire rural area, as also suggested by other authors [64].

\section{Conclusions}

This study highlighted a better nutritional profile of turnip tops of the two rare landraces of Brassica rapa subspecies rapa found to be still cultivated in the province of Foggia in comparison with the more common 'Cima di rapa'. This quality trait is linked to improved contents of vitamin C, total phenols, glucosinolate (in 'Cima di rapa antica'), and K. In the perspective of on-farm conservation of these landraces under the risk of erosion, farmers consumers (local and other) should be aware of the nutritional peculiarities of their products, which are linkable to their genetic characteristics and plant growth environment. Their cultivation and product consumption could be included in forms of ecologically and socioeconomically sustainable production and sale, such as on local didactic farms, 
social gardens, farmer's markets, agritourism, and typical restaurants found both in Monti Dauni and in Gargano. This strategy, along with the commitment of local people to traditional products, meets the increasing general interest of tourists in traditional products and the related nutritional and cultural aspects.

Supplementary Materials: The following are available online at http:/www.mdpi.com/2071-1050/12/9/3842/s1, Figure S1: Turnips (A1), turnip greens (B1), and turnip tops (C1) of 'Cima di rapa antica', and turnips (A2), turnip greens (B2), and turnip tops (C1) of 'Cima di rapa dalla testa' landraces of Brassica rapa subspecies rapa found in the province of Foggia, Puglia region, Italy.

Author Contributions: Conceptualization, G.C.; data curation, A.B.; resources and investigation, C.L.; resources, P.L.R.; funding acquisition, G.C. and A.E.; supervision, G.C.; validation, G.C.; writing —original draft preparation, G.C.; visualization, A.E., writing - review and editing, A.E. and G.C. All authors have read and agreed to the published version of the manuscript.

Funding: This research was funded by the Rural Development Program (RDP) of Puglia Region 2007-2013, Mis. 214/4 sub-action a) and by RDP of Puglia Region 2014-2020 Mis. 10.2., Research Project "Biodiversity of vegetable crops of Puglia region" (BiodiverSO).

Acknowledgments: The authors are grateful to all the growers who kindly donated the plant material.

Conflicts of Interest: The authors declare no conflict of interest. The funders had no role in the design of the study; in the collection, analyses, or interpretation of data; in the writing of the manuscript, or in the decision to publish the results.

\section{References}

1. Negri, V. Agro-biodiversity conservation in Europe: Ethical issues. J. Agric. Environ. Ethics 2005, 18, 3-25. [CrossRef]

2. Jackson, L.E.; Pascual, U.; Hodgkin, T. Utilizing and conserving agrobiodiversity in agricultural landscapes. Agric. Ecosyst. Environ. 2007, 121, 196-210. [CrossRef]

3. Frison, E.A.; Cherfas, J.; Hodgkin, T. Agricultural biodiversity is essential for a sustainable improvement in food and nutrition security. Sustainability 2011, 3, 238-253. [CrossRef]

4. Negri, V.; Maxted, N.; Veteläinen, M. European Landrace Conservation: An Introduction. In European Landraces: On-Farm Conservation Management and Use; Veteläinen, M., Negri, V., Maxted, N., Eds.; Bioversity Technical Bulletin No. 15; Bioversity International: Rome, Italy, 2009; pp. 1-22.

5. Ceccarelli, S. Landraces: Importance and use in breeding and environmentally friendly agronomic systems. In Agrobiodiversity Conservation: Securing the Diversity of Crop Wild Relatives and Landraces; Maxted, N., Dulloo, M.E., Ford-Lloyd, B.V., Frese, L., Iriondo, J.M., Pinheiro de Carvalho, M.A.A., Eds.; CAB International: Wallingford, UK, 2012; pp. 103-117.

6. Kell, S.P.; Maxted, N.; Bilz, M. European crop wild relatives threat assessment: Knowledge gained and lesson learnt. In Agrobiodiversity Conservation: Securing the Diversity of Crop Wild Relatives and Landraces; Maxted, N., Dulloo, M.E., Ford-Lloyd, B.V., Frese, L., Iriondo, J.M., Pinheiro de Carvalho, M.A.A., Eds.; CAB International: Wallingford, UK, 2012; pp. 218-242.

7. Kell, S.P.; Knüpffer, H.; Jury, S.L.; Ford-Lloyd, B.V.; Maxted, N. Crops and wild relatives of the Euro-Mediterranean region: Making and using a conservation catalogue. In Crop Wild Relative Conservation and Use; Maxted, N., Ford-Lloyd, B.V., Kell, S.P., Iriondo, J., Dulloo, E., Turok, J., Eds.; CAB International: Wallingford, UK, 2008; pp. 69-109.

8. Negri, V.; Branca, F.; Castellini, G. Integrating wild plants and landrace conservation in farming systems: A perspective from Italy. In Crop Wild Relative Conservation and Use; Maxted, N., Ford-Lloyd, B.V., Kell, S.P., Iriondo, J., Dulloo, E., Turok, J., Eds.; CAB International: Wallingford, UK, 2008; pp. 392-402.

9. Porter, J.R.; Xie, L.; Challinor, A.J.; Cochrane, K.; Howden, S.M.; Iqbal, M.M.; Lobell, D.B.; Travasso, M.I. Food security and food production systems. In Climate Change 2014: Impacts, Adaptation, and Vulnerability. Part A: Global and Sectoral Aspects. Contribution of Working Group II to the Fifth Assessment Report of the Intergovernmental Panel on Climate Change; Field, C.B., Barros, V.R., Dokken, D.J., Mach, K.J., Mastrandrea, M.D., Bilir, T.E., Chatterjee, M., Ebi, K.L., Estrada, Y.O., Genova, R.C., et al., Eds.; Cambridge University Press: Cambridge, UK, 2014; pp. 485-533. 
10. Torricelli, R.; Pacicco, L.; Bodesmo, M.; Raggi, R.; Negri, V. Assessment of Italian landrace density and species richness: Useful criteria for developing in situ conservation strategies. In Enhancing Crop Genepool Use: Capturing Wild Relative and Landrace Diversity for Crop Improvement; Maxted, N., Dulloo, M.E., Ford-Lloyd, B.V., Eds.; CAB Publishing: Wallingford, UK, 2016; pp. 326-331.

11. Elia, A.; Santamaria, P. Biodiversity in vegetable crops, a heritage to save: The case of the Puglia Region. Ital. J. Agron. 2013, 8, 21-34. [CrossRef]

12. Conversa, G.; Bonasia, A.; Elia, A. Collecting landrace vegetable crops in Puglia region: Case study of Foggia Province. Acta Hortic. 2018, 1215, 453-458. [CrossRef]

13. Reiner, L.; Gladis, T.; Amon, H.; Emmerling-Skala, A. The 'Bavarian Turnip'-A rediscovered local vegetable variety of Brassica rapa L. em. Metzg. var. rapa. Genet. Resour. Crop Evol. 2005, 52, 111-113. [CrossRef]

14. Gowers, S. Swedes and Turnips. In Root and Tuber Crops; Bradshaw, J.E., Ed.; Springer: New York, NY, USA; Dordrecht, The Netherlands; Heidelberg, Germany; London, UK, 2010; pp. 245-289. [CrossRef]

15. Fernandes, F.; Valentão, P.; Sousa, C.; Pereira, J.A.; Seabra, R.M.; Andrade, P.B. Chemical and antioxidative assessment of dietary turnip (Brassica rapa var. rapa L.). Food Chem. 2007, 105, 1003-1010. [CrossRef]

16. Cartea, M.E.; Haro, A.; Obregón, S.; Soengas, P.; Velasco, P. Glucosinolate variation in leaves of ancient crops. Plant Foods Hum. Nutr. 2012, 67, 283-288. [CrossRef]

17. Figliuolo, G.; Cerbino, D. Agro-biodiversity spatial assessment and genetic reserve delineation for the Pollino National Park (Italy). Nat. Resour. 2014, 5, 308-321. [CrossRef]

18. Veteläinen, M.; Negri, V.; Maxted, N. A European strategic approach to conserving crop landraces. In European Landraces: On-Farm Conservation Management and Use; Veteläinen, M., Negri, V., Maxted, N., Eds.; Biodiversity Technical Bulletin No. 15; Bioversity International: Rome, Italy, 2009; pp. 305-325.

19. Pacicco, L.; Bodesmo, M.; Torricelli, R.; Negri, V. A methodological approach to identify agro-biodiversity hotspots for priority in situ conservation of plant genetic resources. PLoS ONE 2018, 13, e0197709. [CrossRef]

20. Montesano, V.; Negro, D.; Sarli, G.; Logozzo, G.; Spagnoletti Zeuli, P. Landraces in inland areas of the Basilicata region, Italy: Monitoring and perspectives for on farm conservation. Genet. Resour. Crop Evol. 2012, 59, 701-716. [CrossRef]

21. Bellon, M.R.; van Etten, J. Climate change and on-farm conservation of crop landraces in centres of diversity. In Plant Genetic Resources and Climate Change; Jackson, M., Ford-Lloyd, B., Parry, M.L., Eds.; CAB International: Wallingford, UK, 2014; pp. 137-150.

22. Wittman, H.; Chappell, M.; Abson, D.; Bezner Kerr, R.; Blesh, J.; Hanspach, J.; Perfecto, I.; Fischer, J. A social-ecological perspective on harmonizing food security and biodiversity conservation. Reg. Environ. Chang. 2017, 17, 1291-1301. [CrossRef] [PubMed]

23. Conversa, G.; Lazzizera, C.; Bonasia, A.; Cifarelli, S.; Losavio, F.; Sonnante, G.; Elia, A. Exploring on-farm agro-biodiversity: A study case of vegetable landraces from Puglia region (Italy). Biodivers. Conserv. 2020, 29, 747-770. [CrossRef]

24. Fracchiolla, M.; Renna, M.; D’Imperio, M.; Lasorella, C.; Santamaria, P.; Cazzato, E. Living Mulch and Organic Fertilization to Improve Weed Management, Yield and Quality of Broccoli Raab in Organic Farming. Plants 2020, 9, 177. [CrossRef]

25. Koh, E.; Charoenprasert, S.; Mitchell, A.E. Effect of organic and conventional cropping systems on ascorbic acid, vitamin C, flavonoids, nitrate, and oxalate in 27 varieties of spinach (Spinacia oleracea L.). J. Agric. Food Chem. 2012, 60, 3144-3150. [CrossRef]

26. Bonasia, A.; Conversa, G.; Lazzizera, C.; Elia, A. Pre-harvest nitrogen and Azoxystrobin application enhances postharvest shelf-life in Butterhead lettuce. Postharvest Biol. Technol. 2013, 85, 67-76. [CrossRef]

27. Conversa, G.; Bonasia, A.; Lazzizera, C.; Elia, A. Bio-physical, physiological, and nutritional aspects of ready-to-use Cima di rapa (Brassica rapa L. subsp. sylvestris L. Janch. var. esculenta Hort.) as affected by conventional and organic growing systems and storage time. Sci. Hortic. 2016, 213, 76-86. [CrossRef]

28. Conversa, G.; Lazzizera, C.; Chiaravalle, A.E.; Miedico, O.; Bonasia, A.; La Rotonda, P.; Elia, A. Selenium fern application and arbuscular mycorrhizal fungi soil inoculation enhance Se content and antioxidant properties of green asparagus (Asparagus officinalis L.) spears. Sci. Hortic. 2019, 252, 176-191. [CrossRef]

29. Pellegrini, N.; Colombi, B.; Salvatore, S.; Brenna, O.V.; Galaverna, G.; Del Rio, D.; Bianchi, M.; Bennett, R.N.; Brighenti, F. Evaluation of antioxidant capacity of some fruit and vegetable foods: Efficiency of extraction of a sequence of solvents. J. Sci. Food Agric. 2007, 87, 103-111. [CrossRef] 
30. Lee, S.K.; Kader, A.A. Preharvest and postharvest factors influencing vitamin C content of horticultural crops. Postharvest Biol. Technol. 2000, 20, 207-220. [CrossRef]

31. Davey, M.W.; Van Montagu, M.; Inze, D.; Sanmartin, M.; Kanellis, A.; Smirnoff, N.; Benzie, I.J.; Strain, J.J.; Favell, D.; Fletcher, J. Plant L-ascorbic acid: Chemistry, function, metabolism, bioavailability and effects of processing. J. Sci. Food Agric. 2000, 80, 825-860. [CrossRef]

32. Gallie, D.R. The role of L-ascorbic acid recycling in responding to environmental stress and in promoting plant growth. J. Exp. Bot. 2013, 64, 433-443. [CrossRef] [PubMed]

33. Domínguez-Perles, R.; Mena, P.; García-Viguera, C.; Moreno, D.A. Brassica Foods as a Dietary Source of Vitamin C: A Review. Crit. Rev. Food Sci. Nutr. 2014, 54, 1076-1091. [CrossRef] [PubMed]

34. Francisco, M.; Velasco, P.; Moreno, D.A.; Garcia-Viguera, C.; Cartea, M.E. Cooking methods of Brassica rapa affect the preservation of glucosinolates, phenolics and vitamin C. Food Res. Int. 2010, 43, 1455-1463. [CrossRef]

35. Martínez, S.; Olmos, I.; Carballo, J.; Franco, I. Quality parameters of Brassica spp. grown in northwest Spain. Int. J. Food Sci. Technol. 2010, 45, 776-783. [CrossRef]

36. Cefola, M.; Amodio, M.L.; Cornacchia, R.; Rinaldi, R.; Vanadia, S.; Colelli, G. Effect of atmosphere composition on the quality of ready-to-use broccoli raab (Brassica rapa L.). J. Sci. Food Agric. 2010, 90, 789-797. [CrossRef]

37. Jahangir, M.; Kim, H.K.; Choi, Y.H.; Verpoorte, R. Health-Affecting Compounds in Brassicaceae. Compr. Rev. Food Sci. Food Saf. 2009, 8, 31-43. [CrossRef]

38. Podsedek, A. Natural antioxidants and antioxidant capacity of Brassica vegetables: A review. LWT-Food Sci. Technol. 2005, 40, 1-11. [CrossRef]

39. Shen, S.S.; Callaghan, D.; Juzwik, C.; Xiong, H.Q.; Huang, P.L.; Zhang, W.D. ABCG2 reduces ROS-mediated toxicity and inflammation: A potential role in Alzheimer's disease. J. Neurochem. 2010, 114, 1590-1604. [CrossRef]

40. Cartea, M.E.; Francisco, M.; Soengas, P.; Velasco, P. Phenolic Compounds in Brassica Vegetables. Molecules 2011, 16, 251-280. [CrossRef]

41. Francisco, M.; Moreno, D.A.; Cartea, M.E.; Ferreres, F.; García-Viguera, C.; Velasco, P. Simultaneous identification of glucosinolates and phenolic compounds in a representative collection of vegetable Brassica rapa. J. Chromatogr. A 2009, 1216, 6611-6619. [CrossRef] [PubMed]

42. Sousa, C.; Taveira, M.; Valentao, P.; Fernandes, F.; Pereira, J.A.; Estevinho, L.; Bento, A.; Ferreres, F.; Seabra, R.M.; Andrade, P.B. Inflorescences of Brassicaceae species as source of bioactive compounds: A comparative study. Food Chem. 2008, 110, 953-961. [CrossRef] [PubMed]

43. Romani, A.; Vignolini, P.; Isolani, L.; Ieri, F.; Heimler, D. HPLC-DAD/MS characterization of flavonoids and hydroxycinnamic derivatives in turnip tops (Brassica rapa L. subsp sylvestris L.). J. Agric. Food Chem. 2006, 54, 1342-1346. [CrossRef] [PubMed]

44. Wang, J.; Fang, X.; Ge, L.; Cao, F.; Zhao, L.; Wang, Z.; Xiao, W. Antitumor, antioxidant and anti-inflammatory activities of kaempferol and its corresponding glycosides and the enzymatic preparation of kaempferol. PLoS ONE 2018, 13, e0197563. [CrossRef] [PubMed]

45. Dong, X.; Meng-Jiao, H.; Yan-Qiu, W.; Yuan-Lu, C. Antioxidant Activities of Quercetin and Its Complexes for Medicinal Application. Molecules 2019, 24, 1123. [CrossRef]

46. Yokozawa, T.; Kim, H.Y.; Cho, E.J.; Choi, J.S.; Chung, H.Y. Antioxidant effects of isorhamnetin 3,7-di-O-?-D-glucopy- ranoside isolated from mustard leaf (Brassica juncea) in rats with streptozotocin-induced diabetes. J. Agric. Food Chem. 2002, 50, 5490-5495. [CrossRef]

47. Padilla, G.; Cartea, M.E.; Velasco, P.; de Haro, A.; Ordas, A. Variation of glucosinolates in vegetable crops of Brassica rapa. Phytochemistry 2007, 68, 536-545. [CrossRef]

48. Cartea, M.E.; Velasco, P. Glucosinolates in Brassica foods: Bioavailability in food and significance for human health. Phytochem. Rev. 2008, 7, 213-229. [CrossRef]

49. Cabello-Hurtado, F.; Gicquel, M.; Esnault, M.A. Evaluation of the antioxidant potential of cauliflower (Brassica oleracea) from a glucosinolate content perspective. Food Chem. 2012, 132, 1003-1009. [CrossRef]

50. Bjorkman, M.; Klingen, I.; Birch, A.N.E.; Bones, A.M.; Bruce, T.J.A.; Johansen, T.J.; Meadow, R.; Molmann, J.; Seljasen, R.; Smart, L.E.; et al. Phytochemicals of Brassicaceae in plant protection and human health—Influences of climate, environment and agronomic practice. Phytochemistry 2011, 72, 538-556. [CrossRef] 
51. Arasu, M.V.; Kim, N.H.; Antonisamy, P.; Yoon, Y.H.; Kim, S.J. Variation of Glucosinolates on Position Orders of Flower Buds in Turnip Rape (Brassica rapa). Saudi J. Biol. Sci. 2017, 24, 562-1566. [CrossRef] [PubMed]

52. Yang, B.; Quiros, C. Survey of glucosinolate variation in leaves of Brassica rapa crops. Genet. Resour. Crop Evol. 2010, 57, 1079-1089. [CrossRef]

53. Francisco, M.; Velasco, P.; Romero, Á.; Vázquez, L.; Cartea, M.E. Sensory quality of turnip greens and turnip tops grown in northwestern Spain. Eur. Food Res. Technol. 2009, 230, 281-290. [CrossRef]

54. Schonhof, I.; Krumbein, A.; Bruckner, B. Genotypic effects on glucosinolates and sensory properties of broccoli and cauliflower. Nahrung-Food 2004, 48, 25-33. [CrossRef] [PubMed]

55. Jones, G.; Sanders, O.G. A sensory profile of turnip greens as affected by variety and maturity. J. Food Sci. 2002, 67, 3126-3129. [CrossRef]

56. Drewnowski, A.; Gomez-Carneros, C. Bitter taste, phytonutrients, and the consumer: A review. Am. J. Clin. Nutr. 2000, 72, 1424-1435. [CrossRef]

57. Vig, A.P.; Rampal, G.; Thind, T.S.; Arora, S. Bio-protective effects of glucosinolates-A review. LWT-Food Sci. Technol. 2009, 42, 1561-1572. [CrossRef]

58. Vicas, S.I.; Teusdea, A.C.; Carbunar, M.; Socaci, S.A.; Socaciu, C. Glucosinolates profile and antioxidant capacity of Romanian Brassica vegetables obtained by organic and conventional agricultural practices. Plant Foods Hum. Nutr. 2013, 68, 313-321. [CrossRef]

59. Santamaria, P. Nitrate in vegetables: Toxicity, content, intake and EC regulation. J. Sci. Food Agric. 2006, 86, 10-17. [CrossRef]

60. Broadley, M.; White, P. Eats roots and leaves. Can edible horticultural crops address dietary calcium, magnesium and potassium deficiencies? Proc. Nutr. Soc. 2010, 69, 601-612. [CrossRef]

61. Accogli, R.; Conversa, G.; Ricciardi, L.; Sonnante, G.; Santamaria, P. Nuovo Almanacco BiodiverSO. Biodiversità delle Specie Orticole della Puglia; Università degli Studi di Bari Aldo Moro: Bari, Italy, 2018; p. 371, ISBN 978-88-6629-024-7.

62. Takada, S.A.; Akter, E.; Itabashi, N.; Nishida, D.J.; Shea, N.; Miyaji, H.; Mehraj, K.; Osabe, M.; Shimizu, T.; TakasakiYasuda, T.; et al. The role of FRIGIDA and FLOWERING LOCUS C genes in flowering time of Brassica rapa leafy vegetables. Sci. Rep. 2019, 9, 13843. [CrossRef] [PubMed]

63. Laghetti, G.; Ghiglione, G.; De Lisi, A.; Maruca, G.; Losavio, F.; Pignone, D. Survey for the conservation of agrobiodiversity in three Italian linguistic (Occitan, Croatian and Franco-Provençal) Islands. J. Biol. Life Sci. 2013, 4, 80-114. [CrossRef]

64. Sturiale, L.; Scuderi, A.; Timpanaro, G.; Matarazzo, B. Sustainable Use and Conservation of the Environmental Resources of the Etna Park (UNESCO Heritage): Evaluation Model Supporting Sustainable Local Development Strategies. Sustainability 2020, 12, 1453. [CrossRef] 